Complutense Journal of English Studies

ISSN: 2386-3935

\title{
Canons in Media Language and Professional Voice ${ }^{1}$
}

\author{
Juan M. Hernández-Campoy²; Juan A. Cutillas-Espinosa ${ }^{3}$
}

\begin{abstract}
Linguistic prescriptivism is an ideology and authority based practice that has traditionally vindicated the use of norms of language as social conventions on correctness, appropriateness, aesthetics and validity, also affecting media language. The aim of this paper is to explore the theoretical underpinnings of the Script Design model, which underlines the need to consider not only responsive and even initiative based performance, but also the script or use of a professional voice, as part of structural constrains, that conditions the individual linguistic behaviour in public occupations. The debate on responsive-initiative motivations in stylistic variation is a central issue of the traditional pendulum-oscillating dilemma in social theory about the relationship between structure and agency, i.e. between sociolinguistic limitations and creativity, and also between speaker intention and listener understanding. Despite their social or regional background, speakers modify their linguistic production in public depending on the market characteristics and the structural constrains. The spirit of the Script Model, therefore, alludes to the standing debate in both classical and contemporary sociological theory over the primacy of social structure or agency in shaping human behaviour and the meaning of human behaviour itself.
\end{abstract}

Keywords: stylistic variation, script design, prescriptivism, standardness, agency.

Contents. 1. Prescriptivism and the Standard Issue. 2. Language and the Media. 3. Objectives. 4. Script Design and the Use of a Professional Voice. 4.1. Consensual Non-linguistic Divergence: Differing from Audience and Speaker Design Practices. 4.2. Consensual Non-linguistic Convergence: Searching for Shared Identity. 5. Conclusion.

How to cite this article: Hernández-Campoy, J.M. \& J.A. Cutillas-Espinosa (2017) Canons in Media Language and Professional Voice, in Complutense Journal of English Studies 25, 49-68.

\section{Prescriptivism and the Standard Issue}

Linguistic prescriptivism is a doctrine that has traditionally vindicated the use of norms of language as social conventions on correctness, appropriateness and validity, affecting all the levels of linguistic analysis - orthography, grammar, semantics, pronunciation and even register (see Hart 1961; Ullman-Margalit 1977; Mil-

1 Financial support for this research has been crucially provided by the DGICT of the Spanish Ministerio de Economía y Competitividad (FFI2014-56084-P) and by Fundación Séneca (19331-PHCS-14), the Murcian Agency for Science and Technology (Programas de Apoyo a la Investigación).

2 Dpto. Filología Inglesa, Facultad de Letras, Universidad de Murcia (Spain)

E-mail: jmcampoy@um.es

3 Dpto. Filología Inglesa, Facultad de Letras, Universidad de Murcia (Spain)

E-mail: jacuti@um.es 
roy and Milroy 1985; Bartsch 1987; or Cameron 1995). This approach is always an ideology and authority based practice (see Milroy 2012) that constitutes a monitoring of individuals' speech and writing with the aim of ensuring the maintenance of some particular valued form or variety as a manifestation of social prestige patterns. For this reason prescriptivism is inevitably associated with purism, whose aim is to protect languages from external influences-usually as a result of language or dialect contact - to avoid any risk of damage of the linguistic system (Langer \& Nesse 2012). This view aims to provide the standards with the minimal variation in form, reducing it to rule, and fixing it permanently so that change and corruption could not affect the language. ${ }^{4}$ Therefore, given than language is paradigmatically a social, public act (see Hernández-Campoy \& Cutillas-Espinosa 2012), according to Cameron (2001: 689), prescriptivism appears as a subset of normative metalinguistic practices aiming at verbal hygiene (see also Cameron 1995).

Linguistic prescription is formally and institutionally regulated in some countries, or language communities, such as, for example, the Real Academia Española de la Lengua, the Académie Française, the Academy of Sciences of Albania, the Office Québécois de la Langue Française, the Academy of Sciences of Moldova, or the Romanian Academy. In Italy the Accademia della Crusca was established in 1582 and had already issued a Vocabolario or dictionary in 1612. Similarly, in France l'Académie Française was founded by cardinal Richelieu in 1635, with a dictionary appearing in 1694 and a Grammar of the French Language (Grammaire de Port-Royal) in 1660. In $18^{\text {th }}$-century England, being influenced by the institutionalisation of the linguistic interventionist practices in Continental Europe, some scholars and writers - such as Edmund Bolton, Francis Bacon, John Dryden, Daniel Defoe, Samuel Johnson, Joseph Addison, or Jonathan Swift — proposed an English Academy as the solution to the problems affecting English - to ascertain, refine and fix it - , but they were not successful (see Baugh and Cable 1935/2012; Romaine 1998; Lass 1999; Brinton and Arnovick 2006/2011; or Hogg and Denison 2006, among others).

The development of prescriptive and purist judgements with the status of canon on what usages are socially proper or politically correct has normally resulted in the establishment of standard varieties (Cheshire \& Stein 1997; Sairio \& PalanderCollin 2012), since one of the main problems of this view is its tendency to favour the linguistic variety of a particular region or social group over others. Therefore, as stated by Havránek (1932/1964), and Haugen (1966) the point of departure for any process of standardisation is the availability of a given variety for the population, which is, in turn, necessarily related to its historicity or rootedness in the cultural heritage of the speech community. The combination of these properties makes the standard be a common link between speakers of different regional origin, who are gradually united into a single group (unifying function) rather than a subdivi-

4 This conservative interventionist position has also had a counterpart, giving rise to the long-standing dichotomy prescriptive vs. descriptive approaches to language in the history of Linguistics: the former made judgements on what was correct and proscribed variation, quite often as a result of mere personal preferences or on the evidence of Latin models - which did not easily suit non-Romance-based language structures (such as English); the latter, contrarily, tended to appeal to usage and custom as definite arbiters of disputed uses (see Cullen 2001). 
sion (separatist function). Historicity and the effects of unification through the acceptance of a national identity unchain attitudes of language loyalty and the attachment of prestige to the standard, which fosters a sentiment of pride and leads to the further development of the intellectualisation and subsequent codification processes, stabilising the standard variety. However, this stability must be flexible and sensitive enough to allow for the modification which might result from sociocultural changes. A frame of reference function is connected with this stability property, as it secures the availability of the codified norm and contributes to the development of an attitude of norm awareness, whereby some members of the group believe that the norms must be enforced as conventional criteria for correctness.

The concept of standard language is inevitably associated with extralinguistic practices, since the rise of linguistic varieties to the status of standard is normally motivated by economic, social, political, geographic and historical circumstances, and is connected to such social practices as the nationalistic centralisation of states. In any process of linguistic standardisation, the promotion of one variety to the status of standard leads to the devaluation of the other linguistic varieties. This means that the development of the standard may eventually lead to the authoritative extension of a class-based use of language as an example of correctness, inducing native speakers to believe that their (dialectal) usage is incorrect (see Trudgill 1975; Milroy and Milroy 1985; Hope 2000). In fact, as Milroy (2001a: 531) states, standardisation constitutes the imposition of a 'legitimised' uniformity upon linguistic variation for (social, economic, political, historical, regional, etc.) prestige reasons. Together with a process of prestige norm focussing, the standard is associated with the idea of correct, adequate and aesthetic, while the nonstandard with that of incorrect, inadequate and even unaesthetic (see Trudgill 1975; Andersson and Trudgill 1990). Invariably, the descriptions of $16^{\text {th }}$-language managers (teachers and literary critics in particular) in Europe, for example, tended to equate the standard variety with correct speech, and consequently disparaged other dialects, which came to be associated with 'uneducated' and 'incorrect' usage. ${ }^{5}$

Yet, the development of a standard language culture, according to Milroy (2007), has made language attitudes be dominated by a standard language ideology and purism in language history and historiography (see Milroy 2001a, 2007, 2012; Riley 2012; or Langer and Nesse 2012), as well as in the reconstruction of prestige patterns (Sairio and Palander-Collin 2012), so that the history of any language is usually the history of its standard variety. The vernaculars were given a marginal treatment, if any, referring to "a form of language (usually speech) that is held to differ in significant ways from the socially approved prestige or standard language" and therefore not accepted "as the language for official transactions or intellectual endeavors" (Macaulay 2001: 420; see also Macaulay 1973, 1997; and

A clue to the awareness of a well-established standard, opposed to 'wrongful' habits, is found in the texts of playwrights. They poke fun at regional speakers by representing their dialects and using them for the parts of boor and buffoon. In the case of English, Shakespeare's plays stand out as examples of this recourse to 'stage dialect', as different extracts from King Lear illustrate. 
Cheshire and Stein 1997). ${ }^{6}$ In standard language cultures, the development of consciousness among speakers of a canonical (correct) form of language comes from authoritative voices and prestige. But "... prestige is conferred on language varieties by speakers, and speakers tend to confer prestige on usages that are considered to be those of the higher social classes. At this point we also become involved with authority: some social groups have more authority than others" (Milroy 2007: 137). Consequently, the social domain of the standard has always been established in relation to authority and prestige, generally acknowledged as the model for the speech and writing of educated speakers, in particular those who have achieved a high level of skill with the written language or those who control the written or broadcast media (Lippi-Green 2012: 59).

\section{Language and the Media}

The study of media language assuming its crucial part in the communicative process and its potential social influence - in terms of audience reception as target - in contemporary society is recent (see Bell 1991; Fairclough 1995; Bell and Garrett 1998; Macdonald 2003; O'Keeffe 2006; Tolson 2006; Machin and Leeuwen 2007; Talbot 2007; or Androutsopoulos 2014, among others). According to Schrøder (2001: 246), the potential ideological impact of media language upon audiences has not been relevant until the 1990s, gaining legitimacy as an academic subject. The prescriptivist standard language ideology also affects media language (Moschonas and Spitzmüller 2010). According to Johnson, Milani and Upton (2010: 241), mass media do not simply inform but also educate audiences in a performative process that "includes the (re)production and propagation of language ideologies, understood as particular views and beliefs about languages and their links to social, political, moral and aesthetic values" (Johnson, Milani and Upton 2010: 241). Mass media "give value and exposure to certain language codes, linguistic varieties, and discourse styles" through the deployment of such codes, varieties and style as shared means of communication (Spitulnik 1999: 149). Media representatives have been conferred status of authority in matters of language, acquiring a role as national models of linguistic appropriacy. In fact, the structures of the linguistic market impose a system of specific sanctions and censorships on speakers as voices of authority to imitate (Bourdieu 1991: 37).

This prescriptivist use of a standard variety in media communication has also traditionally been justified with the idea of intelligibility. From the different definitions obtained by Preston in his studies, Lippi-Green (2012: 60) suggests that the hypothetical standard is the language spoken and written by persons: i) with no regional accent; ii) with more than average or superior education; iii) who are themselves educators or broadcasters; iv) who pay attention to speech, and are not sloppy in terms of pronunciation or grammar; v) who are easily understood by all; and vi) who enter into a consensus of other individuals like themselves about what

6 Although the 1953 UNESCO definition considers the vernacular as a separate language: "[a] language which is the mother tongue of a group which is socially or politically dominated by another group speaking a different language" (UNESCO 1953: 46). 
is proper in language. Therefore, "it seems that we want language to be geographically neutral, because we believe that this neutrality will bring with it a greater range of communication" (Lippi-Green 2012: 60).

After an initial period of solemnity in radio talk, media communication began to be conceived as a dialogic process (Talbot 2007) where direct address to the microphone (imaginary audience) is supplemented with forms of dialogue, engaging with the audience in an interactive, sometimes virtual, relationship. According to Scannell and Cardiff (1991), in the BBC Talks Department, for example, there was a growing realisation that the initial extremely formal and posh form of radio talk was alienating their audience, who did not want to listen to lectures or sermons in their homes. Contrarily, they expected to be spoken to in friendly terms and in ordinary speech. After the 1960s, the search for a more symmetrical relationship between broadcasters and audience - in terms of greater equality and less formality - as well as the outweigh of immediacy and authenticity made modified versions of RP and some regional accents emerge gradually as acceptable mass media language (Schrøder 2001: 254). Consequently, in order to be friendlier to its audiences, media talk began to stress interactivity, performativity and liveliness as crucial defining features of broadcasting (Tolson 2006). In these public contexts: i) audiences have to be active listeners, involving interaction between the presenter and them and suggesting the 'mundanity', spontaneity, naturalness and 'improvisationalness' of real life; ii) the presenter has to permanently adjust the performance to accommodate perceived reactions when addressing an absent and unseen audience; and iii) radio or TV programs and their participants' speech have to look lively ${ }^{7}$, with the spontaneity of performances exhibiting 'authenticity' and 'sincerity' and thus displacing any possible perception of scripted acting. ${ }^{8}$

As Bell (1991: 3) underlined, the study of mass media language can tell us things about media and language themselves as well as about their society:

i. Media have been demonstrated to be a useful source of data for the study of stylistic variation as well as for the real-time measurement and analysis of linguistic variation and change.

ii. Media generates public debate about linguistic usages and their effect upon the community, revealing attitudes and opinions, and acting as a mirror of the wider society and culture.

7 Although, as Tolson (2006: 12) points out, 'liveliness' does not have to be confused with 'liveness' ('happening now'). According to Ellis (2000: 33), “[p]rogrammes adopt the rhetoric of liveness without being literally live. Presenters still adopt the stance of direct address. Not only do they look directly into the camera and adopt a casual person-to-person form of speech, they also use all the indicators of co-presence. They talk of 'now' and 'today', 'here' and 'we'; they use the present tense. They use all those speech indicators whose meaning is context-dependent in order to orient themselves as speaking in the same moment of time as their audience hears them [...] The presence of a live audience (live that is, at the point of recording) will help to ensure that the 'illusion of liveness' is maintained, of course. But the truly remarkable feature of this pervasive television practice is the willing participation of the viewer in this situation".

8 According to Scannell (1996), conversational and interactive forms of broadcast speech communication are embedded in routine practices of everyday life. There is a key link between the ways broadcasting speaks to us, and the ways in which media use punctuates daily existence by emphasising liveliness and immediacy in order to invite us to follow a programme (Tolson 2006: 14). 
iii. Media purveys to us not only a content but also a specific form through language, having a crucial role in affecting language in wider society.

iv. Media language is intended for mass public consumption, which prevents speech production from the observer's paradox usually conditioning sociolinguistic fieldwork.

v. Media language is easier to collect than natural conversation, and is more available in larger quantities.

vi. Media language offers the potential for good quality recording of spoken language.

Correspondingly, Macdonald (2003: 12) refers to four characteristics of media in its relationship with language and society: i) the media reflect reality, ii) the media represent reality, iii) the media operate discursively, and iv) the media offer simulations.

\section{Objectives}

There are some occupations, such as salespersons, receptionists, teachers, or journalists, which, due to their public exposure, somehow involve two kinds of activities: project a public image and linguistic socialisation (Guy 2011: 166). Their degree of standardness tends to be even higher than that of other people belonging to the same level of status, income, or education, because they have some kind of responsibility for promulgating linguistic norms (see Cameron 1995). Speakers modify their speech depending on the market characteristics, and despite their social background-because, given the adequate conditions, they may acquire a higher (or lower) level of sociolinguistic capacity to handle diversely and appropriately in specific situations. In this way, Labov's department store survey (1966: 63-89) showed that behind-the-scenes employees - like stockboys - used far fewer prestige variants than employees dealing with the public — salespersons. Also, the significant correlation of speakers' use of prestige variants with the prestige of the department stores, even among employees doing the same kind of job and with similar income, suggests that the type of linguistic demands an individual faces at work may involve other factors beyond the ones normally used to define social class (Guy 2011: 166).

Companies based on dealing with the public are very aware of the potential impact of language - in terms of ideological effect - on customers or audience (Schrøder 2001). Therefore, they have traditionally assumed the responsibility of promulgating linguistic norms and developed language policies resulting in the imposition of a professional voice to their employees. In her study on the speech of salespersons in the Spanish El Corte Inglés nation-wide chain of general stores, Sánchez-López (2004) found that those sale assistants working in non-standardspeaking regions, like Murcia, admitted during their interview with her to receive voice coaching and communication skills training to deal with clients, with special attention given to the use of Castilian Spanish (the standard prestige variety). In England, Received Pronunciation (RP) has been the British accent used by broadcasting media. Also known as BBC English, Oxford English, or the Queen's English, RP is an accent that does not betray any regional origin. However, RP does 
reveal a high social or educational background, enjoying overt prestige. Although it is used by just 3\% of British population, it is the best understood English accent in the United Kingdom. The radio section of British Broadcasting Corporation (BBC) in the 1920s and its television in the 1950s became an important agent for the diffusion of RP all across Britain, allowing dialectal speakers of English become familiar with the accent. They required an accent that could serve as a model for the 'best' and also the most socially accepted version of oral English. ${ }^{9}$ As Schrøder (2001: 254) states, the selection of the 'appropriate' accent—or 'proper British speech'-for TV and radio broadcasting presenters made the BBC use an exclusive recruitment of speakers of 'Broadcast English', and later 'Received Pronunciation' ${ }^{10}$ as well as create a BBC Advisory Committee on Spoken English until the 1960s (see also Spencer 1957; Gimson 1980; Monroy 1980; Leiner 1983; Macaulay 1988; Ramsaran 1990; Fisher 1996; Mompeán-González and Hernández-Campoy 2001; Milroy 2001b; Fabricius 2002; Mugglestone 2008; or Upton 2008):

This language policy was in line with the paternalist educational aim of publicservice broadcasting in the UK, as well as in many other European countries, where the broadcasting intelligentsia felt a need to establish daily in the minds of the public what correct speech should be. (Schrøder 2001: 254)

The role of this Advisory Committee on Spoken English was seen as a means for standardisation and codification of the English language in the $20^{\text {th }}$ century; i.e., to rule on matters of usage in order to maintain linguistic standards in their broadcasted spoken English. Nevertheless, the advent of commercial radio and television and the search of a more symmetrical relationship between broadcasters and audiences weakened the domination of RP over broadcasting in Britain and some regional accents gradually became acceptable (Leitner 1983).

The situation in the United States was different because radio was, from the beginning, conceived as a commercial endeavour. The plural presence of different accents and styles was crucial to reflect the voices of the intended audiences. However, the main US radio stations (NBC and CBS) initially wanted their announcers to use what is known as 'Network English': a grammatically correct, classless, 'non-accented' English (Brinton \& Arnovick 2011: 423-424):

In fact, in both Great Britain and the United States there has been marked shift in the dynamic between ratio stations and listeners. Radio stations no longer see themselves as custodians of 'good English'; rather, they accommodate their lan-

9 Also, female presenters were also avoided in media broadcasting until the late 1970s because of the lack of social prestige, authority and convincing properties that were assumed in women's voice, deeming them as unsuitable for broadcasting and advertising (see Key 1975; Marecek et al 1978; Eakins and Eakins 1978; Fairclough 1989, 1995, 2000; or Schrøder 2001: 254).

10 Consequently, the association of RP with the BBC led some people to refer to this accent as 'BBC English' (see Spencer 1957: 9; Wakelin 1972: 154; Gimson 1980: 85; Monroy 1980: 12; Wells 1982: 309; or Andersson and Trudgill 1990: 134-135). See also Peter Trudgill's “Time for radio presenter's to get their pronunciation right" in Eastern Daily Mail (24 ${ }^{\text {th }}$ February 2014). 
guage to the speech of their audience. The result has been a 'democratization' of language on radio.

Therefore, linguistic prescriptivism is an ideology and authority based practice that has traditionally vindicated the use of norms of language as social conventions on correctness, appropriateness, aesthetics and validity, also affecting media language. The aim of this paper is to explore the theoretical underpinnings of the Script Design model (Cutillas-Espinosa \& Hernández-Campoy 2006, 2007) retrospectively and in the context of media language, prescriptivism and the standard ideology. As we will see below, this intra-speaker variation model underlines the need to consider not only responsive and even initiative based performance, but also the script or use of a professional voice, as part of structural constrains, that conditions the individual linguistic behaviour in public occupations. The debate on responsiveinitiative motivations in stylistic variation is a central issue of the traditional pendulum-oscillating dilemma in social theory about the relationship between structure and agency, i.e. between sociolinguistic limitations and creativity, and also between speaker intention and listener understanding (Schilling 2013: 342-343; Bell 2014: 305-306): “[a]pproaches which treat speakers as untrammeled agents do not take enough account of the role of structure in interaction and life, just as approaches which treat speakers as sociodemographic correlates did not take adequate account of individual agency" (Bell 2014: 305-306). Structure refers to the social norms that shape as well as constraint the way we live and sociolinguistically behave. Contrarily, agency is our ability to customise that way we live and sociolinguistically behave according to our individual requirements and intentionstaking our own actions, following our own practices, and making our own way and with our own choices (Bell 2014: 305). It is in recent Sociolinguistics that the oscillation of the pendulum is swinging towards agentivity and creativity, and thus moving away from structural constraints and norms (see also Johnstone 2000, 2001).

Chronologically, the indexical nature of the social meaning of inter- and intraspeaker variation in the speakers' sociolinguistic behaviour, as Eckert (2012) suggests, has been approached from three analytic perspectives, or generational waves, which can also be correlated with the main approaches to stylistic variation and the structure-agency debate (see also Schilling 2013): Attention to Speech, Audience Design and Speaker Design. As described by Hernández-Campoy and CutillasEspinosa (2012: 7), in this epistemological evolution since the beginning of Sociolinguistics in the 1960s, there has been a shift from deterministic and systemoriented approaches (language as a collective system: langue) to more social constructionist and speaker-oriented ones (language as individual performance: $p a-$ role). During the 1960s, the mechanistically-based paradigm of the First Generation assumed that speech and the stylistic repertoire were predetermined by major macro-sociological categories, focusing on correlations between sociodemographic categories and patterns of linguistic variation in search of predictable sociolinguistic universals. In the 1980s, the ethnographic-based paradigm of the Second Generation set out that speech and the stylistic repertoire are conditioned by social configurations - rather than global categories - of multiplex relationships within the social networks of speakers and their mobility. More recently, however, at the beginning of the $21^{\text {st }}$ century, a Third Generation of sociolinguists is under- 
lining the individuality of speakers by making use of a constructionist approach based on speaker's agency (individual action), stance and performativity to more accurately account for the nature of the indexical relations between linguistic and extralinguistic variables.

\section{Script Design and the Use of a Professional Voice}

The Script Design model, proposed by Cutillas-Espinosa and Hernández-Campoy (2006, 2007), underlines the need to consider not only responsive and even initiative based performance, but also the script, as part of structural constrains, that conditions the individual linguistic behaviour in public occupations. This view urges us to consider community-specific factors anchored to linguistic norm, correctness and appropriacy restraints in the explanation of stylistic variation. Script takes the form of a professional voice used strictly following a particular linguistic policy which is based on canonical sociolinguistic norms and attitudes to language: not only are linguistic performers to some extent conditioned by audience considerations, since those performing in mass mediated contexts are also constrained by the norms of the particular media and performance event in which they are participating. These norms very often dictate the use of 'standard' linguistic forms as a canon. In these cases, someone somehow guided by the company's language policy has written the script for those public performers and they compliantly make use of it as a way of building as well as projecting an 'acceptable' image and identity, thus determining their public sociolinguistic behaviour. As a result, the sociolinguistic behaviour of a single person "can only be understood in the context of the set of norms that establish the accepted limits of individual freedom" (CutillasEspinosa and Hernández-Campoy 2007: 149). Correspondingly, the codes used (standards vs. non-standard) between professionals and audience, as Schrøder (2001: 247) states, do not need to be identical or convergent, but rather divergent (non-accommodative), since shared identity may perfectly be achieved through non-linguistic means.

This conclusion was reached after studying the speech production of a local radio station presenter and comparatively that of his non-standard-speaking audience in Santomera (Murcia, Spain), as observed in the phone calls received during his programme. ${ }^{11}$ The results showed a radical divergence between the presenter's speech (Standard Castilian Spanish) and that of his audience (Non-standard Murcian Spanish speaking), which by no means match the Audience Design nor Speaker Design theoretical tenets (see Hernández-Campoy 2016). The context therefore is that of a vernacular speech community, since the Spanish spoken in Murcia is a transition non-standard dialect of Peninsular Spanish, predominantly southern, with strong and deeply-rooted connotations of ruralness.

11 MQM (Más Que Música) used to be a music programme broadcasted live by a local radio station (part of Cadena COPE) from Santomera, a small town some 12 kilometres away from Murcia. Its audience participated very actively, by phoning to ask for a song to be played, or to give their number in order to meet other people, or just to talk to the radio presenter. 
The variables examined in this study are prominent features of the Murcian accent, as well as of some other non-standard Southern Peninsular Spanish varieties (see Hernández-Campoy and Trudgill 2002). They are linguistically and sociolinguistically representative of the local dialect both nationally and regionally in Spain (see also Moreno-Fernández and Moreno-Fernández 2002): i) word-final postvocalic /s/ deletion; ii) word-final postvocalic /r/ deletion; iii) word-final postvocalic /1/ deletion; and iv) consonant reduction.

The results show the use of different linguistic codes by the communicator, on the one hand, and his audience interlocutors, on the other, in the interaction during the radio programme. Whereas the audience tends to be less standard (only 13\%) by making use of more non-standard Murcian Spanish variants (87\%) - , the radio presenter, however, exhibits a radically divergent pattern of sociolinguistic behaviour, using more standard Castilian Spanish variants (92\%) for all variables in his broadcasted speech production (see Figure 1). These results, obviously, differ from the Audience Design or Speaker Design theoretical assumptions.

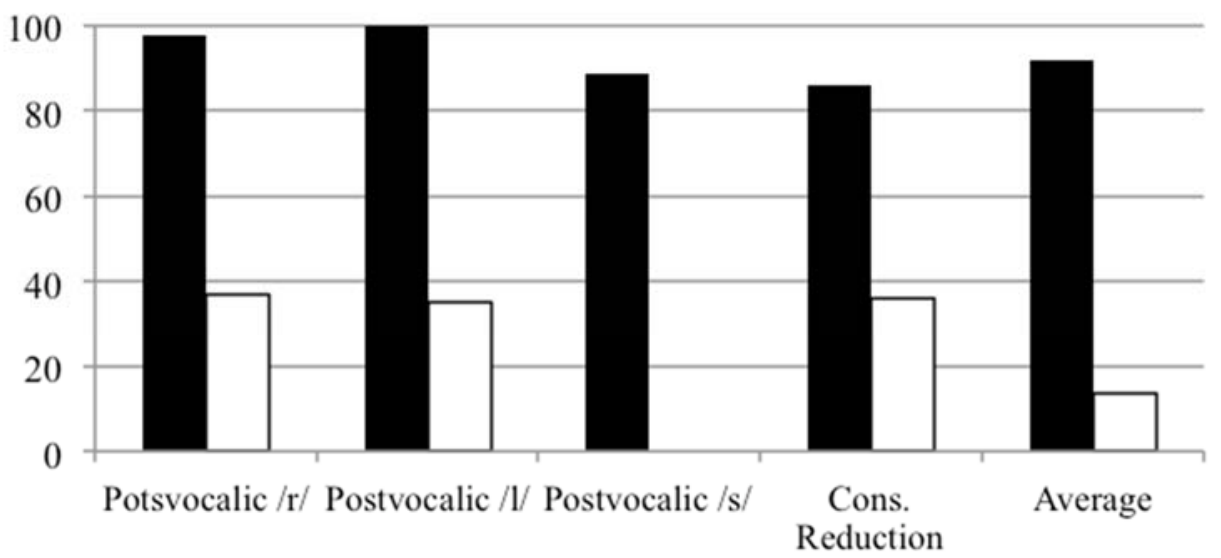

- Presenter $\square$ Audience

Figure 1: Percentage of use of standard forms by presenter and audience interlocutors in the four different variables under study (adapted from Cutillas-Espinosa and HernándezCampoy 2007: 137, Figure 1)

The presenter's speech behaviour during the radio programme 'on the air' was afterwards contrasted with that produced during a private structured interview designed, scheduled and conducted by the researchers themselves. It took place in an informal non-standard-speaking atmosphere and was intended to check whether his high use of standard forms was exclusive to broadcasting or extensive in his everyday use of language. This would ultimately confirm whether his linguistic divergence from the audience interlocutors was a phenomenon related to the mass me- 
dia setting. If while broadcasting the presenter clearly exhibited a deviation from vernacular norms tending towards standardisation (only $8 \%$ non-standard), during the interview, his frequency of non-standard forms dramatically increased to $70 \%$ averagely (see Figure 2).

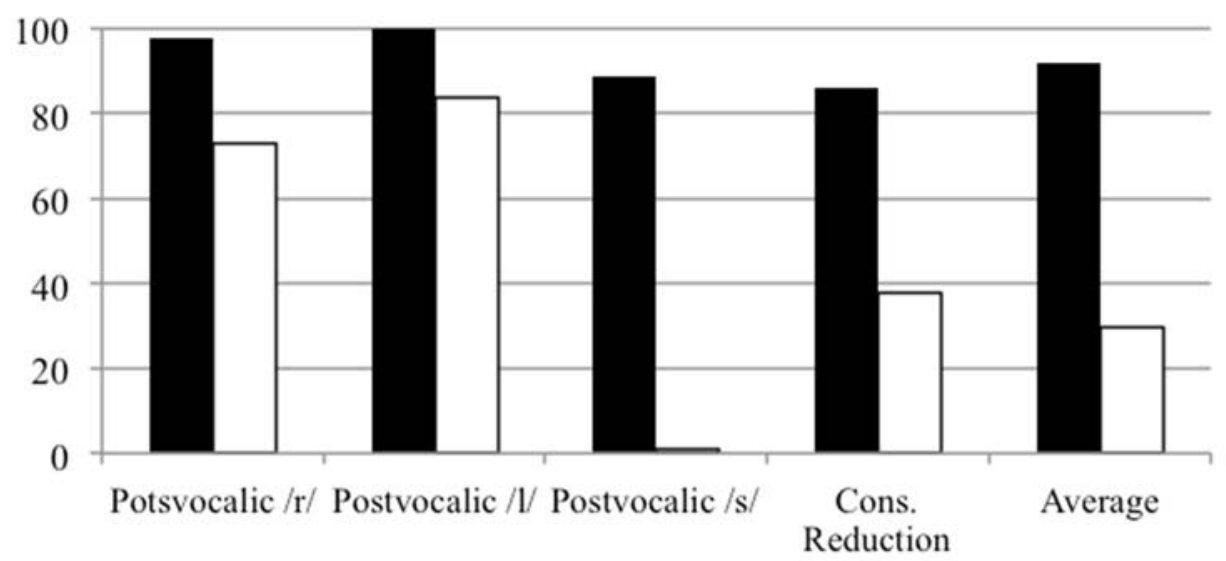

\section{- Broadcasting $\square$ Interview}

Figure 2: Frequency of use of standard forms by radio presenter in broadcasting and in the interview (adapted from Cutillas-Espinosa and Hernández-Campoy 2007: 138, Figure 2)

As a matter of fact, as Figure 3 shows, the speech behaviour of the presenter during the private interview with the researchers and that of the audience interlocutors on the air during the radio programme became much similar now (30\% vs. $13 \%$ standard respectively, as opposed to $92 \%$ vs. $13 \%$ while both broadcasting). 


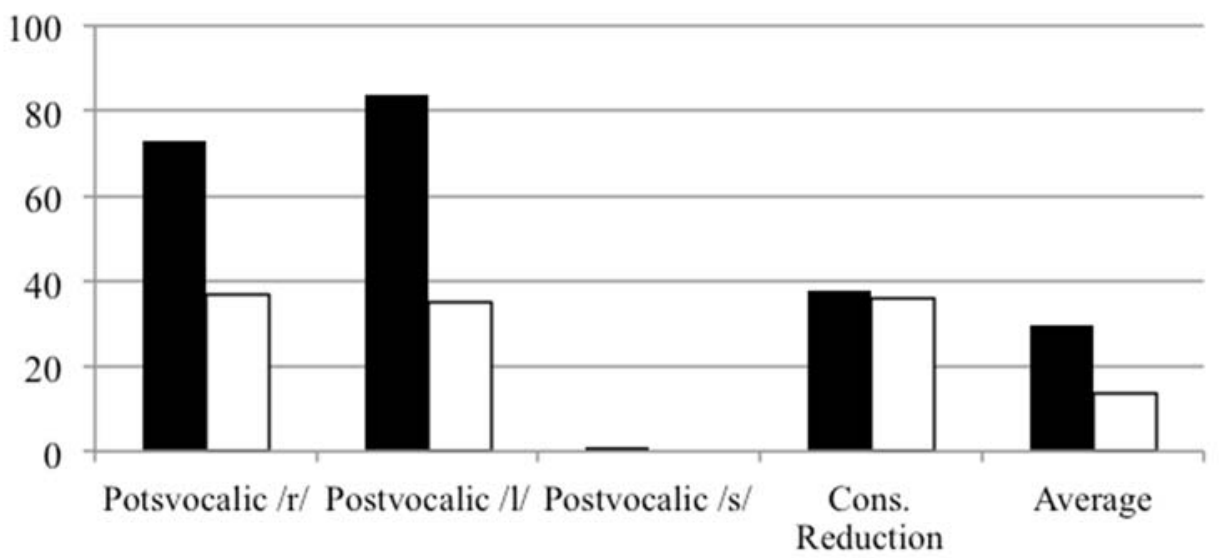

- Presenter $\square$ Audience

Figure 3: Frequency of use of standard forms by radio presenter during the interview and audience on the air (adapted from Cutillas-Espinosa and Hernández-Campoy 2007: 138,

Figure 3)

\subsection{Consensual Non-linguistic Divergence: Differing from Audience and Speaker Design Practices}

Yet the interview was also intended to provide these researchers with qualitative data, in the form of ethnographic fieldwork, eliciting from the presenter opinions that might provide evidence supporting some account of his stylistic behaviour. ${ }^{12}$ The quantitative patterns obtained revealed a particular sociolinguistic behaviour that contradicts the Audience and Speaker Design models, as the radio presenter did not seem to be interested in expressing any kind of shared identity with the audience interlocutors or projecting a particular image, at least by linguistic means. But the interview was even more revealing, since it was inferred that, despite being fully aware of the social profile and linguistic features of his potential audience (Murcian vernacularity), he used to produce a type of speech which - in theorydid not fit them, which is not his own native accent either, and which he did not feel identified with. Audience-based style shifting, in the pioneering sense of Bell (1982a,b; 1984; 1991) or Selting (1983), including ingroup and/or outgroup patterns, cannot thus be confirmed here. But there was no Speaker Design practice either: the recent socio-constructionist model would suggest that the presenter builds a persona (see Coupland 2007; Hernández-Campoy 2016). But the key

12 The questionnaire was devised to obtain information about: i) presenter's awareness of the social and linguistic features of his audience; ii) opinions about nation-wide radio stations, their presenters and their status as models; iii) attitudes to Murcian speech; iv) opinions about media communication and language use; and v) direct questions about the presenter's divergence from his audience interlocutor's speech. 
question here is that, if he does not particularly like the accent he uses at work - as he privately confessed-what are the motivations? He admitted to have received clear guidelines about how to speak from the MQM managers. Their speech while broadcasting is marked by a strict policy of use of a 'correct' and 'intelligible' pronunciation: in broadcasting, there are many people listening and it is inappropriate to use vernacular forms.

Thus, choice of a sociolinguistic behaviour as a professional voice for broadcasting by a media presenter is not a completely free choice, given it has been decided by someone else as a linguistic policy for the radio station; and this decision is based on linguistic attitudes, norms and concepts of appropriacy and correctness in the direction of the standard. In some ways, this structural constraint is also present in Hymes' (1974) contextual parameters configuring any communicative interaction and captured in his acronym SPEAKING: Setting/scene, Participants, Ends, Act sequence, Key, Instrumentalities, Norms of interaction and interpretation, and Genre. In his model, these norms are conceived as the social rules that govern the communicative event as well as the participants' verbal actions and reactions in public. In radio speech, they constitute de facto language policies strictly followed as a basic factor that is always, and almost inevitably, at play. The radio presenter acknowledges to be aware of social attitudes towards the vernacular accent of Murcia, as well as of controversial issues such as standardness and the media language. All these influences are undoubtedly essential in determining his final linguistic performance. His sociolinguistic behaviour during the radio programme is merely a symptom of a social pressure in a particular direction reflected in linguistic policies - more specifically, a whole set of beliefs about the standard accent in Spain, the accent used in the Murcia Region and the appropriate variety to be used in broadcasting. The 'script' appears then understood as a kind of linguistic (language or accent) policy or instructions to be complied with, abstracted from a set of attitudes, norms and beliefs about 'appropriate' and 'correct' speech in a given situation, within a specific community, and which normally-but not always - go in the direction of the standard prestige variety:

In order to understand our presenter's behaviour, we inevitably need to go further than the performance and analyse the script. In doing this we insist on the notion that individual creativity is restricted by rules or structural constraints (see Cameron et al., 1992; Bell, 1999; Eckert, 2000) and suggest that these constraints actually comprise a unit made up of linguistic attitudes, norms and concepts of appropriateness and correctness. This unit is what we call script. (Cutillas-Espinosa and Hernández-Campoy 2007: 144)

This script take the form of a professional voice used as a result of this linguistic policy, which may coincide with the user's linguistic likes or not, as Schrøder (2001: 247) suggested. All these factors contribute to a mental script where the standard as such is hardly under discussion, and non-standard varieties are accepted to be 'wrong' versions of some 'right' linguistic variety, a fact that is reinforced by prescriptive pressures. This pattern is further reinforced by broadcasting managers. Media presenters are instructed to avoid vernacular forms which are regarded as a sign of disrespect to the audience. Pronunciation has to be 'correct', clear and intelligible. Although there does not seem to be anything intrinsically wrong 
about the Murcian accent, from the viewpoint of broadcasting it is seen as inappropriate. These principles are deeply rooted in the mental script of sociolinguistic behaviour of the whole community, in such a way that the audience interprets linguistic divergence as a sign of respect, rather than contempt, distance or unsolidarity, being justified by the wide public sphere of the broadcasting context.

\subsection{Consensual Non-linguistic Convergence: Searching for Shared Identity}

The questions now might be why then the radio programme was so popular among the local audience? Why did the audience remain faithful to the programme despite the presenter's completely divergent speech? As Bell and Johnson (1997) stated, communicators need to persuade their audiences although not necessarily through the use of linguistic means. The Murcia radio presenter used to show identity with his audience by accommodating to their tastes in topics and music rather than linguistically. That is, MQM provided their audience with the music and the conversation they needed. They do it using an accent which, in most cases, is very distant from their own. However, this does not seem to affect their interaction with the presenter. It is assumed as part of the normal communicative conventions in broadcasting, reflecting what Jiménez-Cano and Hernández-Campoy (2004: 83) describe as a diglossic situation in Murcia:

... a bi-dialectal situation - with a diglossic nature - where code-switching or dialect-shift is largely biased by diaphasic and/or diastratic factors: the higher the social class of the speaker, the higher the level of managing more adequately with both dialect varieties in different contexts; and, conversely, the lower the social class of the speaker, the lower the level of having a good command of both varieties, with the use of the local one predominating in most situations.

In this way, the script shared by the presenter and his audience justifies and explains the patterns and linguistic code of their interaction, thus preventing misunderstanding in the form of an offensive interpretation of linguistic divergence.

With these results, Cutillas-Espinosa and Hernández-Campoy (2006, 2007) point at the structural limits to the freedom of speakers to design their style. Speakers do not always build their speech irrespective of sociolinguistic norms, since there may be pre-existing scripts imposed (in terms of rules, attitudes or simply structural constraints) that establish what can be said and what cannot be said. It is within these schemes of social structure that speakers style-shift, making decisions that they consider appropriate to the specific moment under the dictation of social structure. This is especially so in the case of mass media communication, where broadcasting conventions (radio talk norms) and attitudes to the issues of the standard and vernacular forms are essential in order to decide or shape the professional voice to use, conditioning their agency. This is the reason why the behaviour of a local radio presenter in Murcia may not be the same as that of radio presenters in Germany, New Zealand or even Andalusia within Spain itself. ${ }^{13}$ The covert pres-

13 There has been a traditional tolerance for some non-standard accents in Spain. The accents spoken in Andalusia have traditionally been identified with pleasant and cheerful speech, the accent of humour, bull-fighting, 
tige situation in Murcia, with the specific attitudes to the vernacular variety justifies the eradication of local forms in a context where standard forms are selected on an undeniable ideological basis. The listeners are ready to accept that their own loved and hated speech is not appropriate for the radio, where the standard 'correct' speech is, nonetheless, expected. The presenter is therefore recreating, but not creating, a Murcian approach to this linguistic matter. The fact that a media communicator does not try to sound like their radio audience is an interesting counterexample to work like Bell's or Coupland's $(1980,1981)$ about radio presenters who do use accommodative or self-expressive style shifting as a solidarity-building tool.

\section{Conclusion}

Methodologically, research in studies of stylistic variation in Sociolinguistics may be enriched with the combination of quantitative and qualitative methods. By interviewing the speaker through ethnographic work, as shown in this study by Cutillas-Espinosa and Hernández-Campoy $(2006,2007)$, or as conducted in HernándezCampoy \& Cutillas-Espinosa (2013), confirmation or rejection of initial interpretations can be obtained. Without that source of data, the sociolinguist's remarks can always be labelled as judgmental or even subjective.

Theoretically, the fact that a media communicator performs a particular role does not explain the nature itself of that role, since, as these authors point out, the performance itself does not provide an explanation. The concepts of 'normativity', 'correctness' or 'appropriacy' cannot be shoehorned into a fully workable definition of 'script' as a general principle or as a predictive model of style variation, but it is true that 'normativity', for instance, is often a potent constraint on style. The debate on responsive-initiative motivations in stylistic variation in public speech production is a central issue of the traditional pendulum-oscillating dilemma in social theory about the relationship between structure and agency; i.e, the confrontation between structural determination and possibility of human action: the existence of social structures as recurrent patterned arrangements influencing or limiting the creative choices of and opportunities available to an inevitably reactive and responsive individual (see Barker 2000), on the one hand; and interactive human activity as proactive and initiative agents that continuously construct and interpret their own experienced reality, being responsible of the production and perception of that world shared verbally through interactive socialisation, on the other.

There is a 'structural' part in stylistic performance, in the form of script inevitably biasing a professional voice, which we can call 'normativity', 'correctness', 'appropriacy', etc., that also needs to be looked into when attempting to account for stylistic variation. The spirit of the Script Model, therefore, somehow alludes to the standing debate in both classical and contemporary sociological theory over the primacy of social structure or agency in shaping human behaviour and the meaning

traditional singing and all sorts of artistic manifestations. It has also been the accent of power for more than a decade, with a president and vice-president of the National Government (Felipe González and Alfonso Guerra, respectively) exhibiting very marked Andalusian accents. 
of human behaviour itself (Ritzer \& Goodman 1983/2000): is it social structure or human agency that determine the individual's behaviour to construct and/or reconstruct their worlds? Whereas this stylistic theory presented here relies on the constrains of social structure, the recent Speaker Design Model, however, as seen in Coupland (2007) or Johnstone (2000, 2001), extends and fully expands this debate by adhering to the theoretical postulates that stress individual's proactive autonomy and agency.

\section{References}

Andersson, Lars and Peter J. Trudgill (1990). Bad Language. Oxford: Blackwell.

Androutsopoulos, Jannis, ed. (2014). Mediatization and Sociolinguistic Change. Berlin/Boston: Walter de Gruyter.

Barker, Chris (2000). Cultural Studies: Theory and Practice. London: SAGE.

Bartsch, Renate (1987). Norms of Language. London and New York: Longman.

Baugh, Albert C. and Thomas Cable (1935/2012). A History of the English Language, $6^{\text {th }}$ Edition. London: Routledge and Kegan Paul.

Bell, Allan (1982a). Radio: The Style of News Language. Journal of Communication 32: 150-164.

Bell, Allan (1982b). This isn't the BBC: Colonialism in New Zealand English. Applied Linguistics 3: 246-258.

Bell, Allan (1984). Language Style as Audience Design. Language in Society 13: 145-204.

Bell, Allan (1991). The Language of News Media. Oxford: Blackwell.

Bell, Allan (2014). The Guidebook to Sociolinguistics. Malden: Wiley-Blackwell.

Bell, Allan and Peter Garrett, eds. (1998). Approaches to Media Discourse. Oxford: Blackwell.

Bell, Allan and Gary Johnson (1997). Towards a Sociolinguistics of Style. University of Pennsylvania Working Papers in Linguistics 4.1: 1-21.

Bourdieu, Pierre (1991). Language and Symbolic Power. Cambridge: Polity Press.

Brinton, Laurel J. and Leslie K. Arnovick (2006/2011). The English Language. A Linguistic History. $2^{\text {nd }}$ edition. Ontario: Oxford University Press.

Cameron, Deborah (1995). Verbal Hygiene. London: Routledge.

Cameron, Deborah (2001). Verbal Hygiene. In R. Mesthrie, ed., 688-690.

Chambers, J.K. and N. Schilling, eds. (2013). The Handbook of Language Variation and Change. $2^{\text {nd }}$ edition. Oxford: Blackwell.

Cheshire, Jennifer and Dieter Stein, eds. (1997). Taming the Vernacular: From Dialect to Written Standard Language. London: Longman.

Coupland, Nikolas (1980). Style-shifting in a Cardiff Work Setting. Language in Society 9: $1-12$.

Coupland, Nikolas (1981). The Social Differentiation of Functional Language Use: A Sociolinguistic Investigation of Travel Agency Talk. Cardiff: University of Wales Institute of Science and Technology (Ph.D. Dissertation).

Coupland, Nikolas (2007). Style: Language Variation, and Identity. Cambridge: Cambridge University Press.

Cullen, C. (2001). Prescriptive and Descriptive Grammar. In R. Mesthrie, ed., 58-59. 
Cutillas-Espinosa, Juan Antonio and Juan Manuel Hernández-Campoy (2006). Nonresponsive Performance in Radio Broadcasting: A Case Study. Language Variation and Change 18.3: 1-14.

Cutillas-Espinosa, Juan Antonio and Juan Manuel Hernández-Campoy (2007). Script Design in the Media: Radio Talk Norms behind a Professional Voice. Language \& Communication 27.2: 127-152.

Davis, Howard and Paul Walton, eds. (1983). Language, Image, Media. Oxford: Blackwell.

De La Cruz, I., C. Santamaría, C. Tejedor and C. Valero, eds. (2001). La Lingüística Aplicada a Finales del Siglo XX. Ensayos y Propuestas. Alcalá de Henares: Universidad de Alcalá, 707-713.

Duranti, Alessandro, ed. (2001). Key Terms in Language and Culture. Malden, MA: Blackwell.

Duranti, Alessandro, Elinor Ochs and Bambi B. Schieffelin, eds. (2012). The Handbook of Language Socialization. Malden: Wiley-Blackwell.

Eakins, B.W. and R.G. Eakins (1978). Sex Differences in Human Communication. Boston, MA: Houghton Mifflin.

Eckert, Penelope (2012). Three Waves of Variation Study: The Emergence of Meaning in the Study of Sociolinguistic Variation. Annual Review of Anthropology 41: 87-100.

Ellis, John (2000). Seeing Things: Television in the Age of Uncertainty. London: I.B. Tauris.

Fabricius, Anne H. (2002). RP as Sociolinguistic Object. Nordic Journal of English Studies 1: 355-372.

Fairclough, Norman (1989/2001). Language and Power, $2^{\text {nd }}$ edition. London: Longman.

Fairclough, Norman (1995). Media Discourse. London: Edward Arnold.

Fairclough, Norman (2000). New Labour, New Language? London: Routledge.

Fisher, John H. (1996). The Emergence of Standard English. Lexington, KY: University Press of Kentucky.

Gimson, Alfred Charles (1962/1980). An Introduction to the Pronunciation of English, $3^{\text {rd }}$ Edition. London: Arnold.

Guy, Gregory R. (2001). Language, Social Class, and Status. In R. Mesthrie, ed., 159-185.

Hart, Herbert (1961). The Concept of Norm. Oxford: Oxford University Press.

Haugen, Einar (1966). Dialect, language and nation. In J.B. Pride and J. Holmes, eds., 97112.

Havránek, Bohuslav (1932/1964). The Functional Differentiation of the Standard Language. Praguiana: 143-163. Also in P. Garvin, ed. (1964). A Prague School Reader on Esthetics, Literary Structure and Style. Washington: Georgetown University Press, 316.

Hernández Campoy, Juan Manuel (2016). Sociolinguistic Styles. Malden: Wiley-Blackwell. Hernández-Campoy, Juan Manuel and Juan Camilo Conde-Silvestre, eds. (2012). The Handbook of Historical Sociolinguistics. Malden: Wiley-Blackwell.

Hernández Campoy, Juan Manuel and Juan Antonio Cutillas-Espinosa, eds. (2012). StyleShifting in Public: New Perspectives on Stylistic Variation. Amsterdam and Philadelphia: John Benjamins.

Hernández Campoy, Juan Manuel and Juan Antonio Cutillas-Espinosa (2013). The Effects of Public and Individual Language Attitudes on Intra-speaker Variation: A Case Study of Style-shifting. Multilingua 32.1: 79-101.

Hogg, Richard N. and David Denison, eds. (2006). A History of the English Language. Cambridge: Cambridge University Press. 
Hope, Jonathan (2000). Rats, Bats, Sparrows and Dogs: Biology, Linguistics and the Nature of Standard English. In Laura Wright, ed., 49-56.

Hymes, Dell. (1974). Foundations in Sociolinguistics: An Ethnographic Approach. Philadelphia: University of Pennsylvania Press.

Jiménez-Cano, José María and Juan Manuel Hernández-Campoy (2004). Quantifying the Standardisation Process in a Non-standard Local Community: The Case of Murcia. Spanish in Context 1.1: 67-92.

Johnson, Sally and Tommaso M. Milani (2010). Language Ideologies and Media Discourse: Texts, Practices, Politics. London and New York: Continuum.

Johnson, Sally, Tommaso M. Milani and Clive Upton (2010). Language Ideological Debates on the BBC 'Voices' Website: Hypermodality in Theory and Practice. In S. Johnson and T.M. Milani, eds., 223-251.

Johnstone, Barbara (2000). The Individual Voice in Language. Annual Review of Anthropology 29: 405-425.

Johnstone, Barbara (2001). The Individual. In A. Duranti, ed., 122-125.

Key, M.R. (1975). Male/Female Language. Metuchen, NJ: Scarecrow Press.

Kortmann, Bernd and Clive Upton, eds. (2008). Varieties of English. Volume I: The British Isles. Berlin: Mouton de Gruyter.

Labov, William (1966/2006). The Social Stratification of English in New York City, $2^{\text {nd }}$ edition. Cambridge University Press ( $1^{\text {st }}$ edition: Washington D.C.: Center for Applied Linguistics).

Langer, Nils and Agnete Nesse (2012.) Linguistic Purism. In J.M. Hernández-Campoy and J.C. Conde-Silvestre, eds., 607-625.

Lass, Roger, ed. (1999). The Cambridge History of the English Language. Vol. 2: 14761776. Cambridge: Cambridge University Press.

Leitner, Gerhard (1983). The Social Background of the Language of Radio. In H. Davis and P. Walton, eds., 50-74.

Lippi-Green, Rosina (1997/2012). English with an Accent Language, Ideology, and Discrimination in the United States, $2^{\text {nd }}$ edition. Oxon and New York: Routledge.

Llamas, C., L. Mullany and P. Stockwell, eds. (2007). The Routledge Companion to Sociolinguistics. London: Routledge.

Long, Daniel and Dennis R. Preston, eds. (2002). Handbook of Perceptual Dialectology. Vol. 2. Amsterdam and Philadelphia: John Benjamins.

Macaulay Ronald K.S. (1973). Double Standards. American Anthropologist 75: 1324-1337.

Macaulay, Ronald. K.S. (1977). Language, Social Class, and Education: A Glasgow Study. Edinburgh: The University Press.

Macaulay, Ronald K.S. (1988). RP R.I.P. Applied Linguistics 9: 115-123.

Macaulay, Ronald K.S. (1997). Standards and Variation in Urban Speech: Some Examples from Lowland Scots. Amsterdam: John Benjamins.

Macdonald, Myra (2003). Exploring Media Discourse. London: Edward Arnold.

Machin, David and Theo van Leeuwen (2007). Global Media Discourse: A Critical Introduction. Abingdon and New York: Routledge.

Marecek, J., J.A. Piliavin, E. Fitzsimmons, E.C. Krogh, E. Leader and B. Trudell (1978). Women as TV Experts: The Voice of Authority. Journal of Communication 28: 159168.

Mesthrie, Rajend, ed. (2001). Concise Encyclopedia of Sociolinguistics. Oxford: Elsevier.

Milroy, James (1992). Language Variation and Change. On the Historical Sociolinguistics of English. Blackwell: Oxford. 
Milroy, James (2001a). Language Ideologies and the Consequences of Standardization. Journal of Sociolinguistics 5.4: 530-555.

Milroy, James (2001b). Received Pronunciation: Who 'Receives' it and How Long Will it Be 'Received'? Studia Anglica Posnaniensia 36: 15-33.

Milroy, James (2007). The Ideology of the Standard Language. In C. Llamas, L. Mullany and P. Stockwell, eds., 133-148.

Milroy, James (2012). Sociolinguistics and Ideologies in Language History. In J.M. Hernández-Campoy and J.C. Conde-Silvestre, eds., 571-584.

Milroy, James and Lesley Milroy (1985). Authority in Language: Investigating Language Prescription and Stantardisation. London and New York: Routledge and Kegan Paul.

Momma, Haruko and Michael Matto, eds. (2008). A Companion to the History of the English Language. Oxford: Wiley-Blackwell.

Mompeán-González, José Antonio and Juan Manuel Hernández-Campoy (2001). Advantages and Disadvantages of $R P$ as an EFL Model of Pronunciation. In I. De La Cruz, C. Santamaría, C. Tejedor and C. Valero, eds., 707-713.

Monroy, Rafael (1980). La Pronunciación del Inglés RP para Hablantes de Español. Madrid: Paraninfo.

Moreno-Fernández, Julia and Francisco Moreno-Fernández (2002). Madrid Perceptions of Regional Varieties in Spain. In D. Long and D.R. Preston, eds., 295-320.

Moschonas, Spiros and Jürgen Spitzmüller (2010). Prescriptivism in and about the Media: A Comparative Analysis of Corrective Practices in Greece and Germany. In Johnson and Milani, eds., 17-40.

Mugglestone, Linda (2008). The Rise of Received Pronunciation. In H. Momma and M. Matto, eds., 243-250.

O'Keeffe, Anne (2006). Investigating Media Discourse. London and New York: Routledge.

Pride, J.B. and J. Holmes, eds. (1966). Sociolinguistics. Harmondsworth: Penguin

Ramsaran, Susan (1990). RP: Fact and Fiction. In S. Ramsaran, ed., 178-190.

Ramsaran, Susan, ed. (1990). Studies in the Pronunciation of English: A Commemorative Volumen in Honour of A.C. Gimson. London: Routledge.

Riley, Kathleen C. (2012). Language Socialization and Language Ideologies. In A. Duranti, E. Ochs and B.B. Schieffelin, eds., 493-514.

Ritzer, George and Douglas J. Goodman (1983/2000). Modern Sociological Theory, $5^{\text {th }}$ edition. New York: McGraw-Hill.

Romaine, Suzanne, ed. (1998). The Cambridge History of the English Language. Vol. 3: 1776-1997. Cambridge: Cambridge University Press.

Sairio, Anni and Minna Palander-Collin (2012). The Reconstruction of Prestige Patterns in Language History. In J.M. Hernández-Campoy and J.C. Conde-Silvestre, eds., 626-638.

Sánchez-López, Laura (2004). El Habla de los Vendedores de El Corte Inglés de Murcia. Estudio Sociolingüístico. Tonos Digital 8: 117-146.

Scannell, Paddy (1996). Radio, Television and Modern Life. Oxford: Blackwell.

Scannell, Paddy and David Cardiff (1991). Serving the Nation: A Social History of British Broadcasting (vol. 1). Oxford: Blackwell.

Schilling, Natalie (2013). Investigating Stylistic Variation. In J.K. Chambers and N. Schilling, eds., 327-349.

Schrøder, Kim C. (2001). Media Language and Communication. In R. Mesthrie, ed., 246256. 
Selting, Margret (1983). Institutionelle Kommunikation. Stilwechsel als Mittel strategischer Interaktion. Linguistiche Berichte 86: 29-48.

Spencer, John (1957). Received Pronunciation: Some Problems of Interpretation. Lingua 7: 7-29.

Spitulnik, Debra (1999). Media. Journal of Linguistics Anthropology 9: 148-151.

Talbot, Mary (2007). Media Discourse: Representation and Interaction. Edinburgh: Edinburgh University Press.

Tolson, Andrew (2006). Media Talk: Spoken Discourse on TV and Radio. Edinburgh: Edinburgh University Press.

Trudgill, Peter John (1975). Accent, Dialect and the School. London: Edward Arnold.

Ullman-Margalit, Edna (1977). The Emergence of Norms. Oxford: Clarendon Press.

UNESCO (1953). The Use of Vernacular Languages in Education. Paris: United Nations Educational, Scientific, and Cultural Organization.

Upton, Clive (2008). Received Pronunciation. In B. Kortmann and C. Upton, eds., 237-252. Wells, John Christophe (1982). Accents of English: The British Isles (vol. 2). Cambridge: Cambridge University Press.

Wakelin, Martyn F. (1972). English Dialects: an Introduction. London: Athlone Press.

Wright, Laura, ed. (2000), The Development of Standard English, 1300-1800: Theories, Descriptions, Conflicts. Cambridge: Cambridge University Press. 